\title{
KUNSTENS MUSEER, MUSEERNES KUNST?
}

\section{Erik Fischer}

Det var engang i 1920rne, jeg var vel 9 är gammel og min far tog sig omsorgsfuldt af min opdragelse til med tiden at blive et dannet menneske. Derfor beordrede han mig og min syvårige kusine til at gå med på et besøg $i$ Thorvaldsens Museum. Det gjorde vi naturligvis, fulde af nysgerrighed og spanding på forhaind. Vi vandrede andagtsfulde rundt $i$ de smukke, eksotiske sale og så på de mange hvide damer og herrer, som oftest var ganske bare, mens min far fortalte og forklarede. Jeg gjorde mig valdig umage for at blive dannet, mens det kneb lidt mere for min kusine, der havde øjnene alle andre steder henne end $p a$ de adle varker af nyklassicismens danmarksmester. Til sidst blev det kusinen for meget, bun rykkede min far i armet og spurgte med iver i stemmen: Men hvornår begynder det?

I

Hendes forventninger til kulturelle oplevelser gik åbenbart i retning af begivenheder, for hende var kultur ensbetydende med at der skal ske noget, ikke noget med at gå rundt og dvæle mens ånden renses og sindet beriges, forbilledet var nok snarere biografer og børneteatret på Casino. Det statiske museum med tilhørende kultiverede belæringer kedede hende åbenlyst (jeg skal nok holde mund med hvad jeg selv følte!). Min fremmelige kusine fornam måske allerede kunstens ubodelige kedsommelighed i sammenligning med livet selv? Der skete $i$ hvert fald for lidt. Og derved kan jeg i dag ikke lade være med at opfatte hende som en pioner-ånd, der foregreb kulturudviklingen og kulturpolitikken med et halvt århundrede: Der skal ske noget på museerne.

$\mathrm{Da}$ vi omsider forlod Thorvaldsen efter det endeløse besøg, tror jeg at hverken hun eller jeg var blevet mere dannede, eller bedre mennesker. Det varede i hvert fald længe før jeg selv gik på Thorvaldsens Museum igen.

Til gengæld blev jeg snart en flittig gæst på Nationalmuseet og hos ægypterne på Glyptoteket. Der var der nemlig - efter min opfattelse - mening i tingene, for selv om der også var mange billeder på genstandene $\mathrm{i}$ de to museer, så betød både genstandene selv og billederne på dem noget i en historisk sammenhæng, som det var spændende og horisont-udvidende at tilegne sig og forstå.

Jeg mener at vi her står overfor noget centralt når man skal prøve at forstå museumsinstitutionerne: De kulturhistoriske museer er på forhånd spændende, fordi de rækker helt ned til rødderne af den kultur, vi på en eller anden måde altid vil 
32 opfatte som grundlaget for vores egen tilværelse og vores selvforståelse, mens selve det kunstneriske ved kunsten (jeg mener ikke det, de ældre billeder forestiller, eller den beundring, det kan vække, at et billede er dygtigt malet $\mathrm{i}$ den forstand at ligheden med virkeligheden er O.K), altså selve det åndelige i de ting, vi kalder kunst - det er det faktisk ganske vanskeligt og krævende at nærme sig med udbytte. En gang imellem spørger jeg mig selv hvad børn i grunden har ud af at skulle slæbes på kunstmuseer.
II

Som professionelle er det pinedød nødvendigt at vi spørger os selv: er vi egentlig klar over, hvorfor vi anser det for vigtigt at mennesker overhovedet - de voksne og for den sags skyld også børnene - partout skal gå på kunstmuseer? Vi tager det for givet at det skal de, men er det nu så givet? Siden Platon har selve kategorien kunst været forbundet med forestillinger om noget skønt, noget godt og noget sandt. Hvori skønhed, godhed og sandhed end består, så rummer

Hvorfor anser vi det for viktigst, at mennesker overhovedet - de voksne og for den sags skyld ogsa bornene - partou skal gå på kunstmuseum? Musée d'Orsay. Foto Ole Strandgaard

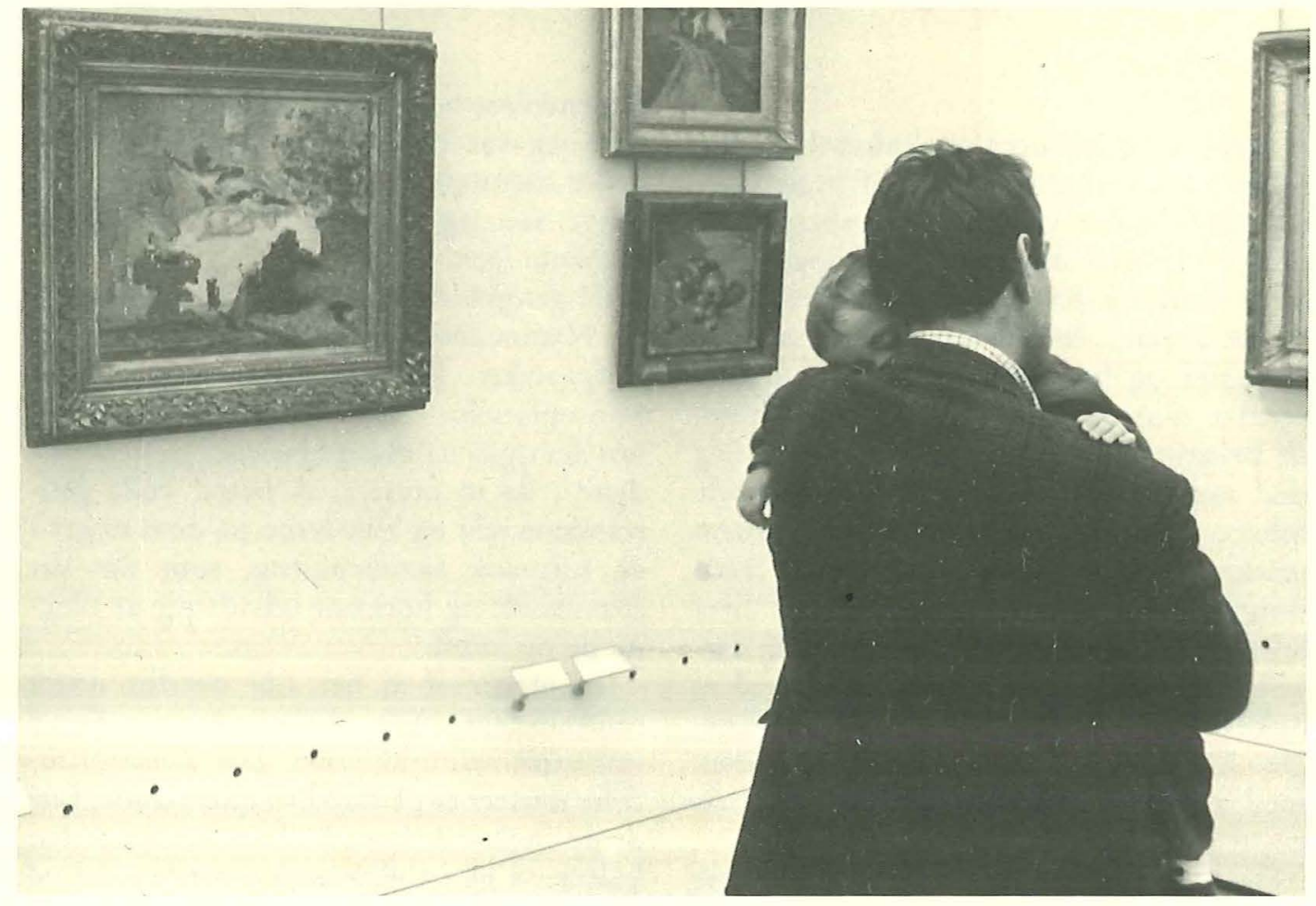


allerede selve ordet kunst så mange positive overtoner, og der antydes så megen positiv afsmitning fra kunsten til andre mennesker, at det må være godt for menneskene at blive konfronteret med kunst, for derved bliver de bedre mennesker.

Kirkens kunst frembar troens gode budskaber, fyrsternes kunst budskabet om den gode magt, som skulle respekteres og forblive uantastet. Og i givet fald skulle kunsten også nok vide af at true dem, der ikke ville annamme troen eller magten. Kunst var budskaber, som de mennesker bestilte, der havde behov for at signalere budskaberne, og budskaberne gik stort set lige godt igennem selv om det ind imellem måske nok kunne være så som så med værkernes skønhed og pragt - eller for den sags skyld med budskabernes sandhed.

Sideløbende med denne udpræget udadrettede kunst opstod der en privat kunst, beregnet for intimsfæren. Det skete først og fremmest i Italien i renaissancen - lad os sige i Firenze og Venezia - hvor mennesker, der havde råd, bestilte sig kunstværker med så sære og eksklusive indhold, at kun den aller nærmeste kreds omkring bestilleren havde mulighed for at løse op for billedindholdets gåder.

$\mathrm{Og}$ her begynder så forudsætningerne for kunstmuseerne at dukke op. I mere eksklusive kredse begyndte man nemlig at samle på kunst - d.v.s. at købe "færdiglavet" kunst, særlig sjælden, særlig fin og kostbar kunst, mærkværdig kunst og gammel kunst. Kunst til at undre sig over, til at glæde øjet og/eller tanken, tillige kunst som statusgivende kostbarheder. På den måde opstod også de danske kongelige samlinger, der i løbet af 1800-tallet kom til at danne grundlaget for hele det danske museumsvæsen.
I glad stolthed over at besidde det kostbare og usædvanlige, åbnede ejerne dørene til deres samlinger for lærde mennesker og for kunstnere, som meldte sig for at beundre og studere samlingerne. De offentlige museer er lige på trapperne - også kunstmuseerne.

\section{III}

Hvad angår den faktiske oprettelse af kunstmuseer, blev et helt afgørende ideologisk skridt efter min mening taget $\mathrm{i}$ 1730rnes Firenze. På det tidspunkt formulerer den sidste af slægten Medici, den barnløse Anna Maria Lodovica, sit testamente, i hvilket hun testamenterer slægtens ufattelige rigdomme på kunstens områder - lad mig bare nævne Uffizierne, Palazzo Pitti, Bargello-museet og Michelangelos Medici-kapel - til staten Toscana, $p \dot{a}$ den betingelse, at disse samlinger aldrig skal fjernes fra byen Firenze, og at samlingerne skal blive til gavn for alle nationers offentlighed. Ordene offentlighed og alle nationer er værd at hefte sig ved. Testamentet fuldbyrdedes ved hendes død i 1743, og hvad fuldbyrdelsen med tiden kom til at betyde for menneskene af alle nationer, vil ingen vel være i tvivl om.

Anna Maria Lodovica formulerede, vist nok som den første, tanken om at gøre en kunstsamling alment tilgængelig for offentligheden, og det kan kun være sket ud fra en forestilling om, at den ordløse billedkunst er et overnationalt udtryk for menneskeåndens idéer og forestillingsevne - at kunsten med andre ord er tilgængelig for alle og af betydning for alle. I museumshistorisk sammenhæng er Anna Maria Lodovica den første, der anslår den ideologi, som er gyldig den dag idag.

I perioden omkring 1800, hvor kunst- 
34 museer begyndte at blive en realitet i mange lande, skrev den tyske romantiker Wilhelm Wackenroder sådan: Billedsale betragtes som markedspladser ... men de burde vare templer, hvor man $i$ tyst og tavs ydmyghed og $i$ hjerte-oploftende ensombed kan beundre de store kunstnere som de bøjeste blandt de jordiske ... Kunsten må blive til en religios karlighed eller en elsket religion. Ordet tempel optræder hyppigt i forbindelse med 1800-tallets kunstmuseer, derimod næppe i forbindelse med de historiske, de kulturhistoriske eller de naturhistoriske museer. De ganske vage forestillinger om kunstens virkning på sjælen, som Aristoteles søgte at udtrykke med ordet katharsis - renselse - denne baggrundsstråling fra æstetikkens big bang ligger helt indlysende til grund for alle de praktiske og rationelle overvejelser i forbindelse med oprettelsen af 1800-tallets kunstmuseer.

\section{IV}

At samle på kunst startede altså som et privat fænomen, et fænomen i intimsfæren, som i grunden ikke skulle deles med andre end med dem, den enkelte kunstbesidder af en eller anden grund fandt det nyttigt eller hyggeligt at invitere hjem. Ud over venner og bekendte udstrakte gæstfriheden sig måske til kunstnere, der ville tage ved lære af mesterværkerne, og til lærde mennesker, der ønskede at forske i kunstens og kunstnernes historie, altså til den slags mennesker, der senere blev til kunsthistorikere og museumsinspektører.

Da kunstmuseerne så kom til i 1800-tallet, flyttedes en ganske væsentlig del af kunstsamlervirksomhed væk fra intimsfæren og over $i$ den offentlige sfære. Publikum kom til, man skulle ikke længere bede om lov til at komme indenfor og se på kunst. Det, man fik lov at se, var i første omgang oftest de samlinger, kongehuse eller fyrstehuse eller andre rige dynastier og familier havde bygget op gennem århundreder - som f.eks. Medicierne for Uffiziernes vedkommende, eller de franske konger for Louvres vedkommende, der åbnede sine døre for offentligheden i 1793.

Lidt anderledes blev udviklingen i London, hvor det var forhold med tilknytning til kunstmarkedet, der i 1827 tvang parlamentet til at oprette The National Gallery og bevilge pengene til køb af en betydelig privat kunstsamling, som ellers ville være blevet solgt til det europæiske fastland.

Og her er vi ved en anden af Kunstmuseernes navlestrenge: Kunsten var i stadigt stigende omfang blevet en vare man handlede med og tjente penge på. Kunsthandlere og auktionshuse kender man siden 1500-tallet, kunstudstillingerne tager deres begyndelse med de franske Salon'er i 1699, men bliver for alvor almindelige i 1700 tallet - og hvordan er det ikke med dem idag! Egentlig var de blevet oprettet, for at kunstakademierne kunne vise, hvad eleverne duede til, men i stadig stigende grad udviklede de sig til at blive kunstnernes årlige marked, hvor man søgte at indfange de købere, kunstnerne efterhånden ikke længere havde særlig megen personlig kontakt med - modsat tidligere, hvor der bestod et nært og præcist defineret gensidigt forhold mellem producenten (kunstneren) og bestilleren (mæcenen), der satte kunstneren igang med ofte klart definerede opgaver.

Ganske gradvis bliver kunstneren den frie kunstner i markedskræfternes vold, den lille hjemmeproducent, der må håbe på at kunne imødekomme kunstmarkedets ubereg- 
nelige behov. Mon ikke det var den slags billedsale, den romantiske Wackenroder tænkte på, da han så beklagende talte om markedspladser?

På dette marked bliver kunstmuseerne så med tiden en ganske afgørende faktor i forholdet mellem kunstner og publikum, for museernes valg/fravalg blandt de årlige udbud bliver hurtigt kendt $\mathrm{i}$ offentlighed og derfor meget afgørende for en kunstners prestige og den placering på markedet, han opnår i kraft af sin prestige. Markedets tabere er de miskendte genier, der for alvor begynder at dukke op samtidig med at kunstmuseerne gør det.

Som endnu en afgørende faktor i kunstmuseerne dukker så museumsmanden op, rigtig for alvor. Museumsmanden, der til at begynde med simpelt hen havde været kunstkenderen, som havde gjort sig dygtig til at identificere og klassificere de enkelte kunstværker, og som måske i ny og næ offentliggjorde en varkfortegnelse over en kunstners arbejder, eller endda forfattede en isoleret kunstnerbiografi .

Men netop samtidig med at de offentligt tilgængelige kunstmuseer kom ind $\mathrm{i}$ verden, så skiftede forskningen karakter: Oven i kunstkenderskabet kom kunstvidenskaben, d.v.s kunsthistorien som historisk og åndshistorisk videnskab. Det videnskabelige sigter mod systematisk tilegnelse og tolkning af fænomenernes helhed, målet bliver de store sammenfatninger og tolkninger af historiske forløb og udviklinger, og videnskaben inddrager fra nu af også de aspekter af kunsten, som ikke umiddelbart var samleobjekter - f.eks. arkitekturen og den væg- og murfaste kunst, der var uløseligt forbunden med arkitektuen.

Udviklingen af en egentlig kunsthistorisk videnskab smittede af på de unge kunst- museer, som satte sig for at foretage systematiske indsamlinger af kunst fra alle perioder, af alle væsentlige mestre, således at alle væsentlige aspekter af den stiludvikling, man nu var begyndt at interessere sig for, kunne repræsenteres, fremvises og forklares på museerne. De besøgende skulle altså ikke bare blive bedre mennesker af at komme på museerne - fordi kunsten nu engang hører til tilværelsens gode ting - de skulle også blive klogere på historiens gang ved at opleve kunstens udvilkling i sammenhæng. Kunstkenderskabet forbliver stadig (og er stadig) noget grundlæggende for museumsansvarligheden, for museerne skal jo gerne vide hvad de gør, og gerne undgå at købe forfalskninger eller kopier eller værker med urigtige tilskrivninger - alle de grundlæggende petitesser, der i sidste instans også hænger sammen med at bruge museets penge på en fornuftig måde og ikke lade sig tage ved næsen af smarte sælgere. Men udover det, stilles der krav til den museumsansvarlige om at besidde et så indgående kendskab til historiens gang, at museet i historisk henseende bliver reprasentativt $\mathrm{i}$ videst mulige omfang. Idealet bliver i 1800-tallet efterhånden det universelle kunsthistoriske museum, som ved hjælp af kunsten formidler en forståelse af, hvad vist nok Julius Lange betegnede som det menneskelige sjalelivs historie.

Med grundlag i kunstmuseernes historie kan vi nok med sindsro sammenfatte meningen med dem på denne måde:

Kunsten er god, sand og skøn og derfor er den til gavn og opbyggelse for alle mennesker, og ikke kun for de udvalgte få, som har råd til at købe den. Derfor opretter man kunstmuseer.

Tidspunktet for oprettelsen af de første kunstmuseer falder nært sammen med det 
36 tidspunkt, hvor historievidenskaben skifter fra at være moraliserende til at blive undersøgende. Historien skal, med Leopold von Rankes ord, undersøge og forklare hvad der $i$ virkeligheden handte. Kunstmuseerne opbygger derfor samlinger, der skal vise kunstens udvikling, og museumsfolkene skal gennem ophængningerne og ved hjælp af talte og skrevne ord forklare, hvordan kunstens historie $i$ virkeligheden er forløbet, og hvilke kræfter, der har styret forløbet.

I sociologisk henseende er tidspunktet for kunstmuseernes opdukken temmelig identisk med det tidspunkt, hvor kunstproduktionen i høj grad er blevet en vareproduktion, hvor den enkelte producent kunstneren - producerer for et åbent marked, bestående af ukendte købere. Kunstneren må helt alene, på egen hånd, finde frem til, hvad der i det givne øjeblik er salgbart. Den egenvillige kunstner, som alene vil følge sit eget hoveds inderste tilbøjelighed, løber en gevaldig risiko for ikke at vinde gehør på markedet, og kan derfor ende som det nye fænomen, der hedder det miskendte geni.

De nye kunstmuseer, som egentlig er historiske museer for den gamle kunst, får snart øjnene op for at historien begynder idag. Derfor begynder museerne at købe samtidens kunst. Ved at gøre det, griber de ind i markedet, sådan som som den stadigt mere omsiggribende kunstkritik allerede gør det. Kunstmuseerne og kunstkritikken bliver magtfaktorer i samtidskunsten. Museerne råder endda over kapital, der kan spenderes på markedet. Gennem deres indkøb vejleder museerne publikum, de kan ophøje og udstøde kunstnere ved deres handlinger eller undladelser, eftersom museumssalg bliver prestigegivende for kunstnerens position i samfundet, og for kunstnerens muligheder for private salg. Både kritikkens og museernes magt kan forværre den egenvillige kunstners skæbne som miskendt geni. Men omvendt kan begge parter hjælpe den egenvillige kunstner til en bedre skæbne end at blive miskendt.

Gradvis dukker der en formidling op i og omkring de nye kunstmuseer. Alt det gode, sande og skønne ved kunsten, som formodes at gøre kunstbetragterne til bedre mennesker, det består stadigvæk, men det suppleres med informationer, der dels går ud på at forklare hvordan publikum bærer sig ad med at blive bedre ved at se på kunst, og dels går ud på nøgternt at forklare kunstens udviklingshistorie, gøre rede for den enkelte kunstners egenart, for hvordan man i billedet kan aflæse kunstnerens budskab, og at forklare de midler, kunstneren betjener sig af for at frembære sit budskab.

\section{V}

Det er altså den slags kunstmuseer, der kommer til verden rundt om i landene i løbet af 1800-tallet. De første blev til mange, og de mange blev til mange flere endnu, og der kommer stadig flere og flere til. Den grundlæggende ideologi bag dem allesammen ligner det, jeg lige har skitseret: Kunsten repræsenterer noget, der er godt og til gavn for menneskene; kunst lader sig bedst tilegne når den anskues i et historisk forløb; kunsten skal formidles i og ud fra museerne; museerne er ikke kun til gavn, glæde og oplysning for publikum, men museerne repræsenterer tilmed et institutionelt mæcenat af aller største betydning for de markedsafhængige samtidskunstnere, både direkte i kraft af indkøbsbevillingerne, og indirekte i kraft af indkøbenes reklameværdi. Med andre ord: en stiltiende accept af kunstens varekarakter. 
VI

For Danmarks vedkommende begyndte det hele, da de århundreder gamle kongelige kunstsamlinger blev gjort offentligt tilgængelige i 1824; det var dem, der i 1896 kom i eget hus og fik navnet Statens Museum for Kunst, Danmarks eneste universalhistoriske kunstmuseum, Danmarks egentlige nationalgalleri.

Provinsen kom snart med, først med kunstmuseet i Aarhus, der startede i 1859 af gode grunde ikke som et universalhistorisk kunstmuseum, men med det implicitte mål at skulle belyse en smuk del af den specielle danske kunsts historie. Det er karakteristisk for de større provinsbyers sociale struktur, at deres kunstmuseer oftest blev oprettet og ledet af ulønnede repræsentanter for det bedrestillede, som regel akademisk uddannede borgerskab, hvis kompleks af dannelsesidealer omfattede troen på kunstens forædlende betydning og borgerdyd i form af forpligtelser overfor nation og offentlighed. Faktisk var det først med den socialdemokratiske kulturlovgivning at provinsmuseerne i løbet af 1960 erne og 70erne fik fast ansatte, musealt og kunsthistorisk uddannede ledere. Uden at vide det præcist tror jeg, at provinsens historiske og kulturhistoriske museer var blevet oprettet på et bredere folkeligt grundlag og adskilligt tidligere kom under professionelt kvalificeret ledelse.

\section{VII}

Men så gik der skred i det hele, da fænomenet modernisme, den moderne kunst, pludselig blev isoleret som en næsten-selvstændig kunstnerisk foreteelse. Formodentlig vil tiden vise, at det var der nok gode grunde til at gøre, selv om jeg personligt mener at kunsthistoriens store "vand- skel" ikke ligger ved Cézanne og Impressionisterne, men så langt tilbage som omkring år 1800, med Goya som en af de mest markante repræsentanter for bruddet med den gamle tradition. Opmærksomme læsere vil notere sig, at dette faktisk falder sammen med det tidspunkt, hvor kunstnerne for alvor bliver producenter til det åbne marked, og med tidspunktet, hvor man begynder at oprette museer for kunsten.

Den første museale konsekvens af erkendelsen af modernismen som et nyt og selvstændigt fænomen, blev New Yorks Museum of Modern Art, der åbnede i 1927. I Danmark blev det Knud W. Jensens Louisiana der åbnede i 1958.

Louisiana blev omgående den store udfordring, havkatten $\mathrm{i}$ de danske kunstmuseers hyttefad. Jensen selv var med rette stolt over sin indsats og holdt sig i de første år ikke tilbage med at tale spydige ord om de "gamle" museer - ikke mindst om Statens Museum for Kunst, som under Jørn Rubows egenvillige ledelse satte en ære $\mathrm{i}$ at være et statisk museum for kunstens evige værdier. Der skete der ikke noget, men det gjorde der til gengæld på Louisiana. Her sprængte Jean Tinguely duer i luften, mens statsminister Kampmann så til fra balkonen, og her slagtede Bjørn Nørgaard heste og puttede dem i syltetøjsglas. Det gjorde man hverken på Statens Museum for Kunst eller for den sags skyld i provinsens. Derfor var de dårlige museer, mens Luisiana til gengæld blev en succes, og det var faktisk noget helt nyt, at et kunstmuseum overhovedet kunne gå hen og blive en succes. Succes havde noget med revyteater, film og underlødige knaldromaner at gøre, ikke mange forestillede sig et succesombrust museum for historie- 
38 forankret, forædlende kunst, lige så lidt som man ville finde på at tale om succesrige gudstjenester. Der klæbede indtil da ligesom noget vulgært og halvdannet ved ordet, og det hørte derfor ikke rigtig hjemme i det ædlere åndslivs verden.

Men det skulle fænomenet succes komme til at gøre. Publikum annammede hurtigt Louisiana, hvor der altid skete noget, og hvor der i øvrigt altid var godt at komme, fordi de ydre rammer var så smukke og venlige. I modsætning til sådan noget som Statens Museum for Kunst, som mange fandt højtidsfuldt, kedeligt og begivenhedsløst - selv om der var ganske fri adgang til Mantegna og Tizian, Frans Hals og Rembrandt, Eckersberg og Købke, Weie og Matisse - alle de evige vardier.

Pressen forelskede sig ganske naturligt i Louisiana, og det gjorde vi andre fra de åbenbart foragtelige gamle museer skam også, dog med noget blandede følelser, netop fordi alt det, vi gjorde og stod for, med eet blev - ja, fiasko og forældet.

Allermest betydningsfuldt blev det, at politikerne $\mathrm{i}$ den grad tog Louisiana til hjertet, at der overhovedet ikke blev plads til overs for nogen form for kærlighed til de gamle museer, som bare var gamle og kedelige. På Louisiana åbnede der ustandseligt nye udstillinger med ferniseringer, hvor kulturministre i højere ærinders tjeneste kunne forlyste sig i selskab med landets kulturelle og sociale elite. På de gamle museer kunne man bare gå rundt $\mathrm{i}$ fred $\mathrm{i}$ selskab med de store mestre, og det var åbenbart knapt så underholdende for ministre og andre.

At Louisiana til sine udstillinger i ganske vid udstrækning kunne trække på de fremragende samlinger af fransk nutidskunst som årvågne musumsfolk på Statens
Museum for Kunst havde opbygget gennem årtier, og som året igennem var frit tilgængelige for alle - det blev der ikke talt ret meget om. Det, der først og fremmest battede, var udstillinger og begivenheder, og først efterhånden fik Louisiana opbygget egne rige samlinger af international nutidskunst som et virkelig betydningsfuldt nyt element $\mathrm{i}$ helheden af vores ellers så danskorienterede kunstmuseer. I alt for lang tid kiggede Louisiana og Statens Museum for Kunst skævt til hinanden, først i det seneste årti eller så har de gradvis opnået en tilstand af fredelig sameksistens, rimeligt gensidig respekt og indbyrdes arbejdsfordeling.

\section{VIII}

Begrebet - eller fænomenet - modernisme vandt først og fremmest indpas på provinsens kunstmuseer, i takt med at de efterhånden alle sammen i løbet af ganske få år kom under ledelse af veluddannede kunsthistorikere og museumsfolk, der tilmed oftest var unge - og det vil sige: yngre i gennemsnit end staben på det efterhånden normeringsmæssigt udsultede Statens Museum for Kunst.

Udviklingen i provinsen hang nøje sammen med den omtalte, nye museumslovgivning. Den nye lovgivning, som supplerede de lokale bevillinger med tilsvarende statslige, kaldte på kommunernes fornyede interesse for deres kunstmuseer. $\mathrm{Og}$ den interesse kom efter min mening til at hænge snævert sammen med hele det postyr på både godt og ondt, som den stort set samtidige lov om Statens Kunstfond gav anledning til. Kunst og kunstmuseer havde alt for længe hovedsagelig været et københavnsk fænomen, og så blev begge dele pludseligt landsdækkende. Kunst og kunst- 
nere blev synliggjort overalt $\mathrm{i}$ landet, kunsten blev et samtaleemne og man blev pludselig nysgerrig efter at få syn for sagn.

Udviklingen på kunstmarkedet, med skyhøje priser, megen omtale i aviserne og store fortjenester at hente for dem, der købte klogt $\mathrm{i}$ rette tid, vakte respekt for selv de tilsyneladende mærkværdigste og mest om- diskuterede fænomener, der dukkede op under navn af at være kunst. Alle slags synliggjorte, formgivne fænomener kunne tilsyneladende lanceres som kunst - var der efterhånden noget som helst om hvilket man med fasthed i stemmen kunne fastslå, at dette i hvert fald ikke var kunst? Angsten for at overse et miskendt geni var stor - i

Louisiana blev omgående den store udfordring, havkatten i de danske kunstmuseers hyttefad. Jean Tinguely: "Skitse til verdens undergang" del af udstillingen "Bevagelse i kunsten", 1961. Foto Jorn Freddie

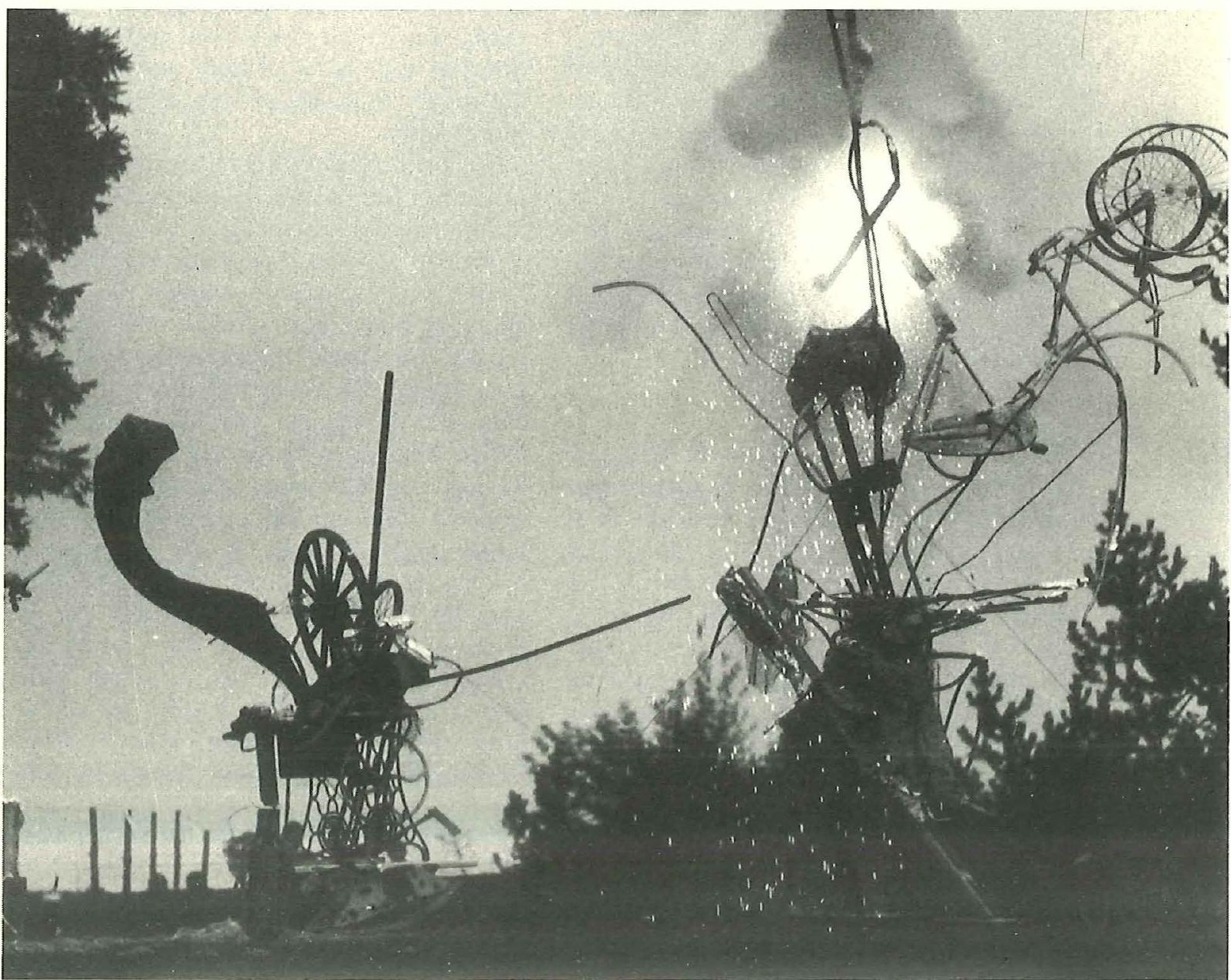


40 farten blev det bare samtidig meget let at overse ikke helt lidt af den gedigne, men upåfaldende, u-mærkværdige kunst, der bare var rigtig god. På museerne førte det til lidt $\mathrm{i}$ retning af en overbudspolitik med hensyn til at være først med det nyeste, ung med de yngste. Og eftersom museerne - i samspil med kunstkritikken, og til en vis grad med kunsthandelen - stadig har status af i nogen grad at være normgivende, og eftersom museerne nu engang lever $\mathrm{i}$ symbiose med kunsthandelen, var den nye handlingsintensitet - først og fremmest i provinsens kunstmuseer - medvirkende til at fremkalde den overophedning af kunstmarkedet, der, også internationalt, var så karakteristisk for de hektiske 80ere. Succes over næsten hele linjen, måske lige bortset fra på Statens Museum for Kunst, der ikke rigtig kunne komme af med Kainsmærket: Her sker der ikke noget. Hverken publikum, pressen eller kunsthandelen var synderligt interesserede $\mathrm{i}$ det museum.

\section{IX}

Men hvormed konstituerer succes sig egentlig? Succes på et nutidigt kunstmuseum synes ene og alene at være betinget af at museet arrangerer udstillinger, hvorimod de permanente samlinger tilsyneladende er aldeles uinteressante $\mathrm{i}$ forhold til om et museum har succes eller ej. Pressen omtaler kun et museum i forbindelse med en udstilling, med mindre da museet kommer $i$ avisen på grund af et tyveri eller en vandskade. Vejen til succes går alene gennem udstillingerne. Udstillinger lokker publikum til, og et rigtigt effektivt nutidsmuseum må råde over et effektivt pressesekretariat, der ustandseligt skal kunne levere nyheder om mageløse besøgstal, om køer og besvimelser på trapperne, om forlængel- se af åbningstider som følge af tilstrømningen.

Måske ikke den helt eneste målestok, men den trods alt afgørende målestok for succes er nemlig besøgstallet. Stort og stigende besøgstal betyder succes, faldende eller lavt besøgstal betyder fiasko. Før i tiden manipulerede museerne vist ikke sjældent i opadgående retning med besøgstallene for at foregive succes, men efter indførelsen af den bedrøvelige entreafgift er dette nok blevet vanskeligere og derfor måske den eneste fordel ved entreafgiften, forudsat man hører til dem, der overhovedet mener at besøgstal i sig selv er særligt interessante.

For hvor interessante er besøgstallene i grunden i forbindelse med kunstmuseernes ideelle, menneskehedsforbedrende og oplysende sigte? Besøgstallet beskriver kun een eneste ting: Nemlig at museets dør bliver åbnet og nogen går indenfor. Hvad det så er, den besøgende foretager sig i museet, hvor længe den besøgende bliver i huset, hvor den besøgende går hen $\mathrm{i}$ huset og hvilket åndeligt udbytte, der kommer ud af besøget - alt det evner statistikken ikke at beskrive. Selv om det er svært at hitte på nogen bedre metode, er det nu alligevel beklemmende, at statistik tillægges så altafgørende betydning som målestok for et museums værdi og succes. Sand fordybelse i kunstværker kræver tid, et enkelt værk kræver i og for sig ikke mindre tid end at høre godt efter en symfoni eller fordybet læsning af en bog. Sand fordybelse kan bevirke, at man "må ændre sit liv", som Rainer Maria Rilke sagde til sig selv. Men den slags eksistentielle forhold, som helt sikkert hører til enhver museumsmedarbejders drømme - dem lader statistikken og jagten på succes aldeles ude af betragtning. 
$X$

Vejen til den statistisk målelige succes og til pressens bevågenhed går altså nemmest og hurtigst gennem de hyppigt skiftende udstillinger af lånt gods. Den slags udstillinger kan i høj grad være værdifulde og vigtige, men de har to priser, som museerne har vist sig villige til at betale. Den ene er, at de koster dyrt hvad angår den interne arbejdskraft, som ofte får meget vanskeligt ved samtidig at holde styr på de permanente samlinger og til at bearbejde og formidle dem. Ser man rundt på landets kunstmuseer er det påfaldende, $\mathrm{i}$ hvor høj grad der mangler ordentlige kataloger, introduktionsliteratur, skrevne undersøgelsesresultater og fortolkninger. Langt den meste åndskraft sættes i sving i forbindelse med udstillingerne og de tilhørende udstillingskataloger, i stedet for at blive kastet af på de nærmeste krav: De permanente samlinger.

Det andet betænkelige led $\mathrm{i}$ at jagte succes gennem udstillinger har at gøre med financieringen af udstillinger. Selv om en række kunstmuseer nu kan trække på en statslig garantiordning (national indemnity) og derved spare store udgifter til forsikring af kunstværkerne, er det stadig kostbart at arrangere udstillinger af hjemlånt gods - ikke mindst fra andre lande - og at publicere de ledsagende kataloger. Så kostbart, at museerne sjældent kan klare udgifterne på grundlag af deres egne normalbudgetter, og derfor må skaffe midlerne i form af engangsbevillinger fra anden side, ofte i form af bevillinger eller garantisummer fra det private erhvervsliv. Den slags kaldes sponsorering, og den er jeg personligt betænkelig ved. Ved at optræde som sponsor opnår den private virksomhed en reklameværdi, og det er der efter min mening måske ved forste øjekast ikke noget voldsomt galt ved at den gør. Ikke mindst fordi der bag sponsoreringen faktisk kan rumstere en tanke om at gøre noget godt og alment nyttigt ved at sætte penge i en god udstilling, som andre lægger arbejdskraft og sagkundskab til.

I forbindelse med den private sponsorering taler nogle om censur, men mange museumsfolk nægter, nogen sinde at have stødt på nogen umiddelbar censur i deres forhandlinger med potentielle sponsorer.

Erfaringer fra sponsorering i sportsverdenen viser imidlertid, at sponsorer kan være der den ene dag og være borte igen den næste, ikke mindst fordi det øjeblikkelige centrum for offentlighedens interesse, der i sidste instans giver sponsoren pote for hans investering, kan have forskudt sig - f.eks. fra sporten til kunsten, eller omvendt eller til noget helt andet potegivende. Sponsorering er altså ikke noget varigt at bygge på. Derfor er det vigtigt, at museerne ikke gør sig sponsorafhængige, men opbygger interne åndelige ressourcer, der også gør det langt mindre omkostningskrævende arbejde med de egne, faste samlinger så interessant, at det alene er nok til at fastholde publikums interesse.

For i sidste instans kommer man nemlig alligevel ikke udenom spørgsmålet om censur i forbindelse med sponsorering. Det siger sig selv, at sponsorer er for pæne mennesker og for kloge til direkte at gå ind i en debat om en planlagt udstillings emne og åndsindhold. Men sponsorer kan jo på den anden side bare sige nej til at bevilge penge til de udstillinger, de ikke har lyst til at sponsorere, fordi udstillingskonceptet ikke vinder deres gehør. Måske fordi de ikke forstår konceptet, eller fordi de misbilliger det. Og det er faktisk censur - nej'ets dis- 
42 krete censur. Et nej til det, der måske skulle være periodens dristigste og aller vigtigste, måske endda kontroversielle, udstillingsidé.

En blot nogenlunde erfaren museumsleder får på ganske kort tid en instinktiv fornemmelse af hvad han/hun ikke kan komme igennem med overfor sine sponsorer, og den slags idéer bortcensurerer museumslederen så selv på forhånd. Selv om det i de gyldne 80ere var muligt at få sponsorer til at gå med på hvadsomhelst. Privat sponsorering spiller næsten uundgåeligt "kunstlivet" over i hænderne på de smarte, velafrettede museumsfolk, der ved hvad der "gør sig" i pressen og hvad de "kan komme igennem med" i forhold til sponsorer. Men bør kunstmuseerne ikke være farligere end som så? Eller omvendt: mindre medløberagtigt på jagt efter succes'er og i højere grad optagne af at vise og tolke værdier i det oversete eller ukendte? Hvor vigtigt det så end er, at nogen formår at opnå midler til at vise Manet, Monet, Krøyer, Bonnard og den gamle Matisse i Vence.

\section{$X I$}

Hvis nogen på baggrund af det hidtil sagte skulle have oparbejdet indtrykket af at det var en ironisk misantrop, der havde talt, så tager de helt og aldeles fejl. Kunstens område - områdets historiske dybde og dets fænomenale bredde - er af så store dimensioner, at det simpelthen er uudtømmeligt for tilegnelsen, for tolkningen og for studiet. Men måske vil jeg tilstå en smule usikkerhed overfor visse mere eller mindre påfaldende tendenser $\mathrm{i}$ nutidens danske kunstmuseer - og det er endda på nogle områder tendenser, som ikke kun de danske museer fremviser.

For nu at blive ved de danske, så kan man til en begyndelse hefte sig ved det gode: at kunstmuseerne er blevet godt og professionelt bemandede; at midlerne til museernes virksomhed i mange tilfælde er blevet rigeligere end før; at der foregår meget på museerne, og at de derfor vækker større interesse og opmærksomhed end før; og at deres internationale orientering og kollegiale kontakter er større og mere virkningsfulde end velsagtens på noget andet tidspunkt. Alt dette har øget museernes handlekraft betydeligt.

Min usikkerhed har at gøre med, om de opnåede fordele nu også udnyttes bedst muligt. Her melder spørgsmålet sig, om museerne er blevet for folgagtige - følgagtige overfor de både udtalte og uudtalte ydre krav om at levere begivenheder og succes'er, målbare med statistikkens numeriske kriterier. Aktivitet for aktivitetens egen skyld. Nyhed for nyhedens skyld. Begivenhed og succes som mål og målestok. Med andre ord: Museet selv som aktivitetens mål, i højere grad end kunsten.

Naturligvis er det ikke sådan, at jeg ser noget ønskværdigt i fiasko, begivenhedsløshed og apati, og naturligvis er det langt fra alt, hvad der sker på museerne, der vækker min skepsis. Skepsis melder sig snarest når museumsvirksomheden vidtgående kommer til at udfolde sig på kunstnernes betingelser og ikke på publikums. Når museumsfolk i ærbødighed underlægger sig kunstnernes filosofi og ideologi - som for tiden forkyndes til overmål - i stedet for at man på museerne forholder sig analytisk og kritisk til kunstnernes ofte dunkle udsagn, lige så kritisk og analytisk som man må formodes at forholde sig til værkerne selv som visuelle fænomener. Kunstværker er meddelelser, og meddelelsen er varket, ikke kunstnerens egen meddelelse om værket. 
Hvad alt det angår er kunst nok blevet vanskeligere at forholde sig til $\mathrm{i}$ dag end nogen sinde før, og det er blevet tilsvarende vanskeligt at være en rigtigt tolkende kunsthistoriker og museumsmedarbejder. Men jeg anser både kunsthistorikeren og museumsmedarbejderen for at være en specialuddannet publikumskategori og finder det derfor vigtigt, at de begge to forholder sig til kunstværkerne som resultat og ikke kun som eksempel på, og som manifestation af, ideologi. I kunsten er der ofte lang afstand mellem det i værket manifesterede, og den af kunstneren deklarerede, til grund liggende ideologi. Ideologidebatten omkring kunstværket ender let med at blive et lukket kredsløb omkring kunstværket, med kun få referencer ind $i$ kunstværket, og kunsthistorikerens akcept af at føre en sådan debat bliver ganske ofte den rene følgagtighed. Et kunstværk må først og fremmest tolkes på selve det synliges betingelser. Først i en sekundær fase kan det - måske være lønnende at kigge nærmere på den postulerede ideologi og filosofi.

Ustandseligt får vi stukket svar i næsen endnu inden vi har nået at se længe nok på kunstværket til selv at finde ud af hvad vi overhovedet føler det nødvendigt at spørge om. Sagt lige ud mener jeg, at museerne er tilbøjelige til at ligge under for en slags kunstnernes og kunstnerordenes tyranni, og derved svigter de deres publikum. Ligesom de efter min mening i alt for høj grad ligger under for det politiske tyranni, der manifesterer sig i kravene om udstillinger, begivenheder og succes'er. Men dette sidste er det naturligvis let nok at sige for en, der ikke længere selv er med i heksedansen.

Vi har altså kunstens museer, endda flere af dem end nogensinde før, mere ombejlede og mere omtalte end nogensinde før.
Og her er jeg så endelig fremme ved mit sidste spørgsmål, min sidste tvivl: hvad skal vi med dem? De er der naturligvis for kunstens skyld, for kunst er jo så vigtig og betydningsfuld. Men hvorfor er den nu det? Hvorfor skal kunsten da vare sa vigtig for så mange? Hvad skal vi i grunden med skidtet? Det er et spørgsmål, som mærkværdigvis næsten aldrig stilles og derfor heller aldrig besvares. Men skal det da slet ikke stilles? Skal .akcepten af den hellige, almindelige kunst bare konstateres som værende for hånden, stiltiende og uargumenteret? Var det ikke på tide at just museerne stillede det - og endda søgte at besvare det?

\section{SUMMARY}

\section{The Art in Museums, the Art of Museums?}

Some time in the late twenties my father, wanting to introduce me to the delights of higher civilisation, invited myself, then hardly ten years old, and my somewhat younger cousin to visit the Thorwaldsen Museum. Losing himself in enthusiastic expoundings, my father soon forgot all about time until my candid cousin pulled his sleeve, asking him with evident signs of boredom when does it begin? thus indicating expectations not of aesthetic bliss but of excitements similar to those so very familiar to an already experienced cinéaste.

In retrospect my cousin appears a herald of future developments within museum policy: tranquil contemplation of masterpieces being hardly the aim any longer, something must happen, activity must manifest itself in sensations and perpetual success, statistically measurable by ever growing numbers of visitors. Still in the twenties the very word "success" had slightly vulgar connotations associating the word with music-halls and American best-sellers, but hardly with spiritual or intellectual activities like visits to museums.

Since statistical evaluations of the importance of any 
ERIK FISCHER

44 museum merely describe the number of people who go through entrance but not what happens subsequently, nor the duration or the spiritual or intellectual benefit of the visit, they should be considered as being of very limited value. Despite this fact we possess no better means of evaluating a museum's success.

After considering in some detail the ancient belief in the purifying potential of works of art, the coming into existence of art museums, of collectors, critics, curators and the art market, as well as discussing briefly the interactions of such factors, the essay concludes by asking the following desperate questions:

Art is allegedly very important, but in many ways it is an extremely complicated subject. Must it necessarily be important to all people? What do we want from art? Must the importance of art necessarily be accepted without argument? It seems a strange fact that such questions are hardly ever raised by those involved in criticism and curatorship and consequently are hardly ever answered. Instead, art is treated like a continuously self-generating perpetuum mobile. Has the time not come for such questions to be asked by museums and even somehow answered?

Erik Fischer er mag.art $i$ kunsthistorie, museumsinspektor ved Den kgl. Kobberstiksamling, Statens Museum for Kunst fra 1948, leder 1957-90. Lektor i Kunsthistorie ved Kobenhavns Universitet 1964-90, Dr. phil. honoris causa ved Kobenhavns Universitet 1991.

(Adr: Agergårdsvej 5, Ammendrup, DK-3200 Helsinge)

NOTER

1 G.F. Young: The Medici 1910, cit. efter udg. New York (The Modern Library) 1930, 739f.)

2 Wackenroder: Herzensergiessungen eines kunstlieben den Klosterbruders (1797), citeret efter Volker Plagemann: Das deutsche Kunstmuseum 17901879 (München 1967), 25. 